\title{
Principled Disobedience in the EU
}

\author{
Jonathan White \\ London School of Economics \\ Forthcoming, Constellations
}

\begin{abstract}
The article examines how the contestation of policy in the European Union increasingly depends on a willingness to break rules. It develops an account of what a politics of disobedience in this context may look like, the kinds of political agent that can lead it, and the normative basis on which to distinguish it from illegitimate forms of extra-legality.
\end{abstract}

One of the striking features of European politics post-2010 is how discretion exercised in the name of crisis management has been coupled with keen efforts to establish new rules.* Warding off renewed disorder is said to demand heightened constraints on political initiative. Though some may be spared these controls - the design of the rules leaves more powerful agents undisturbed - for those in a subordinate position they have considerable binding force. Governments and parliaments across the EU are amongst those increasingly hemmed in. An effort to normalise the post-crisis order has taken the form of limiting these agents' room for manoeuvre.

An important implication is that those wishing to reshape the order arising may be compelled to do so by rule-breaking means. As policy requirements are locked in, a challenge by procedural means is precisely what is rendered less feasible. This matters not least because an order instituted under the sign of emergency may be a highly imperfect one, in normative terms especially. Built in haste by agents whose mandate for far-reaching change is slim, it may be quite undesirable to play by the rules it institutes. But if one rightly has concerns about the unbound character of emergency rule, how can one defend the kinds of transgression that may be required to overturn its political legacy?

In this paper I explore the political and normative underpinnings on which a disobedient politics may rest. Drawing on criteria inspired by theories of civil disobedience, adapted to the transnational context, I discuss the basis on which such contestation may legitimately proceed, and what may distinguish it from the measures it is intended to challenge. Central, I suggest, are a number of features: the readiness to submit actions to public approval, the justification of goals by reference to generalizable principles, and an

\footnotetext{
* For feedback and comments on an earlier draft I thank Dominic Burbidge, Marco Dani, Richard Ekins, Andreas Kalyvas, Paul Linden-Retek, Claus Offe, Peter Niesen, Markus Patberg, Lea Ypi and the Journal's referees. The paper was presented at Oxford, Flensburg and Krkonoše in summer 2016.
} 
underlying commitment to achieving a genuine constitutional order. I discuss the agents best placed to meet these criteria, and argue for a concept of disobedience that includes action pursued through political institutions as well as outside.

In the light of the Syriza experience in 2015, when the threat of disobedience towards the demands of the emerging Eurozone regime was evoked only to be soon discarded, the prospects for resistance of this kind in the EU may currently seem remote. Indeed, given the scale of the power resources that can apparently be applied to forestall it, consideration of the normative basis for such a counter-politics may seem wholly premature. Yet this has not stopped central figures in the Syriza experiment issuing calls for a politics of 'civil, civic and governmental disobedience' in the EU, the theoretical basis of which deserves further consideration. ${ }^{1}$ Moreover, what the Greek episode also showed was the confidence with which charges of 'irresponsibility' are levelled at those who toy with the prospect of defaulting on their obligations, and the symbolic force of appeals to "play by the rules'. It seems appropriate to consider whether there are not circumstances in which 'irresponsibility' may have its place, and to investigate the criteria that might regulate it.

With far-Right populists in Europe poised to make electoral advances, there is added significance to the question. Vocal dissent towards rules made in Brussels is a cornerstone of these parties' appeal, and there is no reluctance to invoke defiance of EU rules, either as rhetoric or as political strategy. Disobedience is a game the far Right can play, in the service of an undifferentiated hostility to the political establishment. Taking critical distance from these positions, and obstructing their monopoly of opposition to the post-crisis EU, requires that we reflect more closely on the criteria that separate legitimate forms of disobedience from the dubious.

First though it is necessary to examine the conditions under which a politics of disobedience becomes relevant, which is the task of the following section.

\section{Why Disobedience?}

The political order emerging from the Euro crisis includes a significant body of new binding demands. One need only recall the stipulations included in the Fiscal Compact concerning how states are to balance their accounts. The requirement that Eurozone members give constitutional status to a 'debt brake' on public finances has drawn particular attention, as

\footnotetext{
${ }^{1}$ Varoufakis 2016, https://yanisvaroufakis.eu/2016/09/08/europes-left-after-brexit/
} 
has the requirement that states submit their budgets to the Commission for approval. ${ }^{2}$ The requirements associated with the European Stability Mechanism (ESM) likewise set farreaching policy conditions on participating states in return for access to loans. ${ }^{3}$ Such demands confront states of the Eurozone, some more pointedly than others, as significant constraints on their political discretion, as the standoff between Greece and the Council in the summer of 2015 reminded.

As many have argued, it would be misleading to see these new demands as amounting to the strengthening of the rule of law. ${ }^{4}$ There remains significant space for arbitrary discretion for those who have the power to claim it, whether they be the governments of the largest member-states or supranational agents such as the Commission and European Central Bank. ${ }^{5}$ Furthermore, the sheer variety of measures that have been instituted, and the quite different legal foundations they rely on, severely compromise the coherence and intelligibility of the resulting framework. ${ }^{6}$ As a distinguished legal scholar observes, EU law has been devalued by cynical use, employed as a stabilising tool without sensitivity for norms and generalizable aims, and in an uneasy relation with public international law. While rules are increasingly abundant, the larger process they give rise to is one of de-legalisation. ${ }^{7}$

It is commonly observed that the unconventional actions taken in response to crises have a tendency to become quasi-permanent. The prospects for their roll-back are difficult, particularly if the crisis itself is widely seen to be long-lasting. ${ }^{8}$ One reason is that the measures instituted may easily come to seem necessary so as to avert a return to crisis. The will to undo them is weak: they take their place as the 'new normal'. ${ }^{9}$ But where there is the will to contest them, by what channels can it find expression?

I am interested here in how such rules and conditions may be challenged as opposed to avoided. Clearly an exit from the EU is an option available to those seeking to escape such demands, more or less feasible in the particular case. But such a response disputes the application of these constraints to a particular set of actors rather than their very

\footnotetext{
${ }^{2}$ See esp. Art 3(2) TSCG.

${ }^{3}$ It should be noted that many constraints, being directed at specific actors, lack the generality typically associated with law, and therefore do not necessarily produce direct legal obligations (cf. Kilpatrick 2015, p.340). This does not make them any less restrictive however, especially given the pressure placed on states to seek the loans that activate them.

${ }^{4}$ See e.g. Chalmers, Jachtenfuchs and Joerges 2016, pp.9-11; on 'bonded government', see Chalmers in the same volume, pp.275ff.

${ }^{5}$ Scharpf 2014.

${ }^{6}$ Kilpatrick 2015.

${ }^{7}$ See Joerges in Chalmers, Jachtenfuchs and Joerges 2016, esp. p.308.

${ }^{8}$ Kreuder-Sonnen 2016.

${ }^{9}$ Cf. White 2015 b.
} 
existence as such. Extrication, not contestation, is the logic of exit. So what options exist for contestation? Three approaches present themselves.

The first mode by which the accretions of emergency rule may be challenged is by ordinary legislative means. In the EU, this conventionally involves an intergovernmental decision by state representatives in the Council, supported in some measure by the involvement of the European Parliament, and in response to proposals formulated by the Commission. Crucially, such an approach is in principle compatible with legal and political norms: it need not mark a renewal of the exceptional means associated with emergency rule, nor need it feature a form of 'disobedience' of the kind discussed below. This is the approach advocated by a number of sympathetic critics of the post-crisis EU, who consider its current arrangements unsustainable yet who do not wish to advocate its dissolution. ${ }^{10}$

There are good reasons to see this mode of contestation as the ideal. It draws on the legitimacy of established institutions, national and supranational, and upholds the principle of a rule-bound order while challenging the specifics of the order as found. It reaffirms the EU's long-standing self-image as the achievement of 'integration by law'. A polity that undergoes such a transition promises to emerge from its period of emergency rule with its legitimate authority renewed.

Appealing as it may be in principle, such an approach faces very sizeable obstacles, particularly in a setting characterised by the diffusion of political power. Reaching a decision by this method requires, depending on the policy area, the unanimity of EU member-states or the consensus of a large majority. For the case in question - the reversal of the measures associated i.a. with the Fiscal Compact and ESM - any such hurdle will not easily be crossed. To the extent that states retain the same governments that instituted these measures in the first place, a reversal requires their willingness to overturn their own decisions, something they are likely to be reluctant to do. To the extent national parliaments were also involved in approving these measures, even a change of government may be insufficient to change the dynamics. Absent additional pressure of the kind we shall discuss, a constellation for change is unlikely to be forthcoming. As with the Council, so with the Commission: continuity of personnel obstructs a major shift in policy.

Those who see the EU as subject to the hegemony of a single state - Germany may feel there is in fact only one veto player, and that the direction of EU decision-making hangs predominantly on German domestic politics and the composition of government

\footnotetext{
${ }^{10}$ E.g. Habermas 2013.
} 
arising. ${ }^{11}$ Though an adequate engagement with this argument needs more space than can be given here, ${ }^{12}$ it should be enough to recall that EU decision-making in recent years has not always mirrored the preferences of the German government. Especially the interventions of the IMF and the ECB have challenged it at key moments, as have the positions of other national governments. ${ }^{13}$ One may infer that the structure of the EU order depends on considerably more than the politics of just one country.

A judicial response to emergency rule is the second to consider. Could it be that courts are able to unpick what others are unwilling or unable to undo? The possibility is commonly evoked by scholars of emergency politics in the national context. ${ }^{14} \mathrm{~A}$ heavily judicialised order such as the EU would seem to display the appropriate conditions. Yet as is well known, the indications to date have been that the CJEU is unwilling to contest the measures introduced for the sake of crisis management. Indeed, the main judgements of relevance (Pringle 2012 on ESM, and the 2015 ruling on OMT) have served rather to give those measures the stamp of legality, thereby contributing to their consolidation. As a range of authors have noted, ${ }^{15}$ the response of the CJEU in this period has been to reinforce the discretion of the powerful rather than challenge it. What are we to make of the acquiescence of the court best placed to contest transnational decisions from a transnational perspective?

One of the structural problems for a judicial response to emergency rule is that, in the transnational context especially, the executive actions in question are not easily classed as illegal. The 'incompleteness' of the EU constitutional order means that, however dense the framework of rules in certain areas, there are zones of action over which the binding capacity of law is quite limited. The willingness of executive agents to step outside the EU legal structure altogether when seeking to institute measures in the face of anticipated resistance, as in the case of the ESM and the Fiscal Compact, further limits the reach of the EU judiciary. Intergovernmental compacts are never likely to be effectively challenged by the CJEU. Where EU law poses an unwelcome constraint, the more powerful agents can avoid it. ${ }^{16}$

But this can only be part of the story, given the number of legal scholars who do indeed observe illegal actions in the making of the new regime for the post-crisis era, ${ }^{17}$ and

\footnotetext{
${ }^{11}$ On German hegemony: Beck 2013. On the European significance of German politics: Habermas 2013.

${ }^{12}$ For the sketch of an appraisal: White 2015a.

${ }^{13}$ Cf. Schaefer 2015.

${ }^{14}$ Dyzenhaus 2006.

${ }^{15}$ See Kilpatrick 2015; Everson and Joerges 2014; Scicluna 2014.

${ }^{16}$ Scicluna 2014, p.557.

${ }^{17}$ E.g. Fischer-Lescano 2014; Joerges 2016.
} 
more generally given the past willingness of the CJEU to adopt an activist stance and claim jurisdictional authority in areas where its status is ambiguous. ${ }^{18}$ Two further explanations of judicial acquiescence are the following. First, there is the general problem that, were a court to conclude that major illegal acts were conducted over a sustained period, it would severely put in question the credibility of the legal order of which it is guardian. Especially for an international court, inclined to bolster what remains a contested legal order, this would be a major concession. Tempting surely to conclude instead that the initiatives taken were actually consistent with the law. ${ }^{19}$

Second, there is a problem of epistemic authority. Where emergency measures rest on claims to a kind of expertise - in the Eurozone context, economic expertise and experience in crisis management - then the contentious agent sets itself against this expertise. Such a stance is a difficult one to assume for the small number of persons charged with arriving at a judicial decision. Few judges can be expected to challenge such measures when the consensus of a much larger group is that to do so would reignite the crisis. The deference accorded to the 'expertise' of the ECB is one of the notable features of the CJEU's decision on OMT of $16^{\text {th }}$ June 2015, and before it of the Opinion of the Court's Advocate General delivered on $14^{\text {th }}$ January 2015. As one observer summarises in relation to the Pringle decision, 'was there ever any doubt that the Court would rule as it did given the stakes involved? 20

This is hardly to say courts are irrelevant to the contestation of crisis measures. Some national courts have been more confrontational than the CJEU, albeit from a national perspective. $^{21}$ But one may strongly doubt that a judicial response alone is sufficient. In any case, once a court finds such actions to be legal, the decision is unlikely to be reversed: the window of opportunity is brief.

If we exclude then both an ordinary legislative approach and a purely judicial one, there is one further response that shares with these the characteristic of not requiring further rule-breaking. We might call it malicious compliance. Its point of departure is that the assemblage of rules and commands arising from emergency rule are very likely to display tensions, both with each other and with the pre-crisis order. The speedy and ad hoc fashion

\footnotetext{
${ }^{18}$ Kilpatrick 2015, p.352.

${ }^{19}$ It may be countered that legal orders are actually built conflictually, exactly by finding and penalising transgressions: this may be true where the transgressions are local in character, but when they are on the systemic scale seen in the Euro crisis this argument is much less plausible.

${ }^{20}$ Scicluna 2014, p.564.

${ }^{21}$ See notably the Portuguese and German national courts, though currently these remain exceptions (KreuderSonnen 2015; Chalmers in Chalmers et al 2016, p.283). Exploring some of the possibilities for contestation by national courts: Joerges in Chalmers et al 2016.
} 
in which such measures are introduced generally undermines the formal coherence of the resulting framework, while the tailoring of measures to very specific concerns means they may rapidly become obsolete as the context changes. This may suggest that what is needed to overturn them is no more than dogmatic adherence to them so that their internal tensions undermine them.

Malicious compliance is a strategy usually associated with trade unions seeking to contest workplace conditions. Such tactics as work-to-rule involve adhering to the letter of contractual obligations so as to reveal their dysfunctionality and / or dependence on discretionary interventions. The approach is in principle transferable to a larger political unit. In the context of the contemporary EU, the demands associated with the Fiscal Compact are a potential target, not least since the austerity measures they require are widely observed to be economically unsustainable. ${ }^{22}$ Even the broadly sympathetic Economist magazine has had reason to note that strict adhesion to Eurozone banking rules could have fundamentally destabilising consequences. With admirable prudence, if a want of imagination, it concludes: 'there is no point in following rules to the letter, if doing so leads to the demise of the single currency. ${ }^{23}$

As a form of contestation, one distinctive plus of malicious compliance is its invulnerability to sanction. Because it aims to challenge rules from within, it can be pursued without risk of compromising its protagonists before the law, and without giving executive powers further reason to introduce constraining measures. Furthermore, because malicious compliance is essentially reactive, it requires no programmatic agreement amongst those practicing it about the political alternatives they would like to see. It can be pursued by actors of contrasting political orientation.

Malicious compliance is an under-theorised notion that invites further scrutiny, but a significant shortcoming should be noted: the tensions it aims to highlight can typically be alleviated or resolved in multiple ways, only some of which are socially desirable. In principle they can be addressed by sacrificing good rules and norms just as well as bad ones. As a stand-alone strategy, malicious compliance is silent on the question of how tensions in the rules framework are to be addressed. The effort to ensure normative and not merely functional criteria are brought to bear on the resolution of such tensions is likely to require more focused forms of contestation. For this reason I conclude that it is no more a sufficient response than the two previous kinds discussed.

\footnotetext{
${ }^{22}$ See e.g. Blyth 2013.

${ }^{23}$ See The Economist leader, 'The Italian Job', $9^{\text {th }}$ July 2016, p.9.
} 


\section{$\underline{\text { Disobedience in a Multilevel Order }}$}

It seems then that to contest the order emerging from the Euro crisis in a rule-abiding way may be difficult. If a framework instituted under the sign of emergency is to be challenged, it seems likely that opponents will need to engage in acts of transgression bearing some similarity with the manoeuvres by which these measures were first instituted. Indeed, it may be that acts of contestation will tend to require the breach of rules more explicitly than emergency rule itself, since - in the transnational context especially - they must proceed within a rules framework shaped at least partly by the needs of those powers wielding discretion.

Not only may transgressions be hard to avoid, but there is an argument that it is intrinsically desirable that at least some measures be challenged in this way. We may assume that one aim of contestation is to raise critical public attitudes: it may be that open disobedience has a valuable capacity to do this. ${ }^{24}$ If emergency rule relies on securitisation, such that exceptional measures are advocated as necessary responses to urgent threats, then disobedience can be seen as a step towards $d e$-securitisation and re-politicisation. ${ }^{25}$ If it can be shown that breaching such rules does not produce chaos, opposition actors thereby challenge the logic of emergency that formed their rationale. The breach of rules thus has a performative function: it contests the necessity of those rules, and thereby contests the symbolic power used to establish them.

Is disobedience a relevant notion in a voluntary association such as the EU? Those who form part of a transnational polity are said to be there by their own consent - does the exit option remove the grounds for disobedience? There are normative aspects to this question we shall return to in the following section, but in a practical sense the exit option does not fundamentally change things. Unless there are procedures available for expelling the disobedient (which exist neither in the EU in general nor the Eurozone specifically), disobedience remains a viable option to the extent that those seeking change on balance prefer membership over exit.

Discussions of the politically-motivated transgression of rules tend to focus on street-level direct action. Civil disobedience is typically construed as occurring outside the

\footnotetext{
${ }^{24}$ Cf. Scheuerman 2015, p.5.

${ }^{25}$ On de-securitisation: Aradau 2004.
} 
institutions of political representation, displaying for this reason such virtues as spontaneity and horizontal organisation. ${ }^{26}$ This concept of disobedience is not without relevance to the transnational sphere: an expanding body of work has examined resistance by social movements to EU politics, including the mobilisations associated with the Indignados, Aganaktismenoi and Occupy. ${ }^{27}$

But the transnational context also affords a less discussed form of political disobedience, one waged within political institutions. To the extent that the setting is a 'post-sovereign' one, with power diffused across multiple institutions rather than concentrated at an agreed centre, the decisions enacted through some institutions can be contested by agents housed in others. To hold a position of government at the national level is at the same time to hold a position from which to oppose decisions made at the transnational level. The agents of disobedience may therefore include those located in executive and legislative institutions. ${ }^{28}$

This notion of institutional power as a site of principled disobedience is one way to get a handle on the actions of Syriza in the first half of 2015. One would overlook something essential if one saw the Greek governing party's actions as simply a form of state diplomacy in defence of national interests: the ends in play were more far-reaching, in a way well captured with the concept of principled disobedience. One sees this logic especially clearly if one considers one of the movements later emerging from the failure of Syriza's efforts to reshape the EU in this period. The DiEM25 movement, initiated in 2015 by former Syriza figure Yanis Varoufakis, proposes in one of its programmatic statements 'a pan-European movement of civil and governmental disobedience with which to bring on a surge of democratic opposition to the way European elites do business at the local, national and EU levels. ${ }^{29}$ In contrast to EU withdrawal, the suggestion is that the regime emerging from the crisis period can be challenged from within. Advocated is 'a clash with the European establishment based on a campaign of wilfully disobeying the unenforceable EU "rules" at the municipal, regional and national levels while making no move whatsoever to

\footnotetext{
${ }^{26}$ Celikates 2016a, p.39 offers a definition of civil disobedience which can be applied to our case: 'an intentionally unlawful and principled collective act of protest (in contrast to both legal protest and "ordinary" criminal offenses or "unmotivated" rioting), with which citizens - in the broad sense that goes beyond those recognized as citizens by a particular state - pursue the political aim of changing specific laws, policies or institutions'.

${ }^{27}$ See e.g. Celikates, Kreide, and Wesche 2015, esp Douzinas chapter.

${ }^{28}$ We may note in passing that similar points may apply also in certain decentralized federal systems. While ideas of civil disobedience have rarely been applied to the institutional framework of the EU, an interesting discussion of disobedience led by judiciaries is Baquerro-Cruz 2012 (cf. Kumm 2012). See also Goodin 2005 , who connects criteria of civil disobedience to the transgressions needed to reshape international customary law, and Wagner 2015, who examines the new forms of citizen disobedience afforded by cross-border mobility.

${ }^{29}$ Varoufakis 2016.
} 
leave the EU.' In keeping with the early policy of Syriza, 'rebel governments and finance ministers' are presented as some of the key agents of disobedience, but the stated aim is to involve governmental institutions at all levels. ${ }^{30}$

As such calls suggest, contesting power through institutions has some distinctive qualities unmatched by street-level disobedience alone. Though this particular statement includes few details on the rules to be challenged, ${ }^{31}$ it seems clear the rationale is both to demonstrate the inadequacy of Eurozone rules and to contest them in a way that strikes directly at their effectiveness. The EU's long-established insulation of decision-making from popular interference means that systemic challenges to it, more than simply highlighting critical opinion, may need to disrupt its functioning too. The demands associated with the European Semester - on public spending, on the release of economic data - are demands that have street-level effects but which in the first instance bind governments rather than citizens, and it is the actions of the former that determine their success. The same holds of the rules of procedure that support their implementation - e.g. the non-public character of discussions concerning the meeting of budgetary requirements. These can be challenged directly only on an institutional footing.

Disobedience outside the nation-state setting is not without its very real challenges, conceptual as well as practical. One of the most significant concerns its addressee. If principled rule-breaking involves an effort to convince a larger public of the unsustainability of the status quo, who is that public in this context? Clearly there is a nationalist or statist response to this question: the public is that of the nation-state, incited to see the EU more critically and to call for changes in the state's relation to it. But in a context where decisionmaking is transnational, meaningful contestation may need to be too. Indeed, as we shall observe in the final section, there may be strong reasons of principle why the agents of disobedience in a transnational polity should construct their constituency as a transnational one and their rule-breaking actions as irreducible to the pursuit of local interests. The question would be whether there is a cross-border social formation that can support such claims. Can one expect receptiveness to notions of a European interest, and enough shared moral intuitions to permit a common critique of the status quo?

A strategy of disobedience demands the assumption that, even if such a constituency is weakly formed, it can be cultivated through the process of contestation itself. The gamble is that a convergence of outlooks can emerge through political mobilisation

\footnotetext{
${ }^{30}$ Ibid.

${ }^{31}$ The statement speaks of their further elaboration in a 'Progressive Agenda for Europe' still in development.
} 
rather than act as its necessary precondition. (Varoufakis defines the aim of disobedience not as to activate a public already fully-constituted but to 'create the European demos that will bring about Europe's democracy. ${ }^{32}$ ) The plausibility of such a view has long been debated in the normative theory of the EU and we need not revisit the 'demos debate' here. ${ }^{33}$ It is clear that disobedient actors in the transnational setting lack some major resources by which to shape a constituency for their claims. For one, the absence of a written constitution articulating shared norms in a popular idiom deprives them of a reference-point by which to show up the failings of the status quo. Unlike those in a constitutionalised setting, agents will struggle to point to codified commitments that the existing order fails to honour. How consequential these barriers are, and whether they can be politically overcome, is something that can only the practice of disobedience itself can ascertain. Efforts to decide on this question in advance by sociological means - by reference to divisions of language, reported feelings of identity, and the like - are always liable to overstate the determining effect of existing structures.

The idea of principled disobedience as an institutional practice also raises a challenging question concerning the status of the agents that wage it. When conceived as street-level action, disobedience is visibly the action of moral agents - of individuals exercising their moral judgement and bearing the attendant risks of punishment. If one extends the concept to an institutional setting, the worry will be that one ends up ascribing a dubious moral capacity to institutions themselves. ${ }^{34}$ Can one somehow assert that the agents of disobedience remain persons, albeit acting by different channels? I think one can, but only if one emphasises the crucial role of intermediary actors such as parties and movements. To the extent that such associations are defined by shared purposes and genuinely express a form of collective intentionality, ${ }^{35}$ they are agents to which judgement and responsibility can be ascribed. When they gain majority control of institutions, they establish the kind of 'authorship' of decision-making that less cohesive entities with no claim to programmatic unity - including the state itself and its organs of bureaucracy - are themselves little able to offer.

Transnational partisanship in the EU is often approached as a question of the making of a party system in the European Parliament. It is conceived as the closing of a

\footnotetext{
32 Varoufakis 2016.

${ }^{33}$ For a recent overview, see Innerarity 2014; cf. White 2011.

${ }^{34}$ Cf. Scheuerman 2016 b, p. 240 for discussion.

${ }^{35}$ Many ruling parties today are rather less than this of course: they are the 'hollowed' (Mair) vehicles of a political class. Our remarks can only apply to parties organised on a more genuinely collective basis (cf. the next section).
} 
democratic deficit, based on making political choices available to citizens through the mechanisms of party competition. An alternative account of the normative point of transnational partisanship locates it in the construction of the political will and capacity to reshape transnational structures. ${ }^{36}$ Forms of institutional disobedience can be seen as a contextual variation on this theme, where it is exactly the associative character of partisanship that gives disobedience its collective subject.

A lingering suspicion may be that disobedience drawing on the capacities of existing institutions will inevitably tend to be conservative. If one goes by the aims of DiEM25, this seems wide of the mark. Quite in contrast to Rawlsian notions of using disobedience to correct the very specific failings of a 'nearly just' order, ${ }^{37}$ the stated objective is the EU's transformation, and, should this fail, its 'collapse or disintegration' in a way that does the least political damage. ${ }^{38}$ Although existing institutions are part of the means, the aim is to alert a wider public to deep-lying failures in the existing order. Ultimately a form of disobedience focused on institutions should not be viewed as an alternative to extra-institutional forms but as a complement. Acting through institutions is typically slow, and may rely on the support of more direct forms of mobilisation. If the larger story of movement/organisation relations in contemporary politics is increasingly that of cross-over and double-membership, ${ }^{39}$ this holds too for the question of disobedience.

\section{$\underline{\text { Normative foundations of a disobedient politics }}$}

When might efforts to challenge the contemporary EU order, with the infringement of rules and commands this may entail, be considered defensible acts of principle? In what sense is there scope for such moves to be viewed differently from the unconventional measures they oppose? Moreover, how can one conceive disobedience in a way that does not simply reproduce the anti-establishment orientations of the populist far Right and thereby give wind to disagreeable forms of contention?

\footnotetext{
${ }^{36}$ Cf. White 2014.

${ }^{37}$ Rawls 1999 [1971], pp.319ff.

${ }^{38}$ Varoufakis 2016: '[E]ither they [the EU's leading executive powers] will blink (in which case the EU will be transformed) or the EU will be torn asunder by its own Establishment. If the Establishment (the Commission, the European Central Bank, Berlin and Paris) dismember the EU to punish progressive governments that refused to abide by their inane policies, this will galvanise progressive politics across Europe in a manner that Lexit could never do.' ('Lexit' is the term widely used for the prospect of a state leaving the EU to pursue an agenda further to the left than the EU structures are said to permit.)

${ }^{39}$ Cf. Della Porta and Chironi 2015; Dean 2016.
} 
Drawing on contemporary discussions of the normativity of civil disobedience, adapted to the transnational context, I suggest three standards as follows. ${ }^{40}$ Taken cumulatively, they allow principled disobedience to be marked off from outwardly similar forms of exceptionalism and extra-legality, achieving thereby a status that is normatively distinct. These can be expressed as: a) a readiness to submit actions to public approval; b) a commitment to generalizable justification; and c) commitment to achieving a genuine constitutional order. We may examine each more closely as follows.

a) Agents intending to work outside the existing framework of rules need to invoke a nonprocedural authority in support of their actions. In the case of well-established political elites, this often takes the form of a claim to technical expertise and effectiveness. Executives powers present themselves as having special insight into the situation at hand by virtue of theoretical and practical knowledge unavailable to those outside their circle, or based on a capacity to respond swiftly and effectively to threats which others are illequipped to manage. They may seek thereby to authorise themselves to go beyond the rules for the sake of the spirit of the rules. But for those seeking to contest such moves 'from below', authority claims of this kind will typically be unavailable. The kind of knowledge certified as expertise may be exactly what they wish to challenge, and speedy 'fire-fighting' actions the kind likely to reproduce the defects of the status quo.

An alternative source of authority - and one the established powers are often badly able to claim - is the readiness to submit actions to public approval. Agents of exceptional action who demonstrate this willingness have one basis on which to authorise their departures from the constraints of existing politico-legal frameworks. By inviting the involvement and evaluation of a wider public, they acknowledge their actions must not be unchecked. In effect, they substitute an alternative form of constraint - that of public approval - for the constraint that is offered by rules. They take an important step thereby towards distinguishing their actions from arbitrary or narrowly self-interested forms of political discretion.

There are diverse ways in which this authority can be claimed. The willingness to contest an election or referendum with reference to the disobedience proposed is one. The 'No' of the Greek referendum of $5^{\text {th }}$ July 2015 offered the Syriza-led government further backing for a strategy of non-compliance with the demands of the eurozone's

\footnotetext{
${ }^{40}$ For recent interventions, and some important points of disagreement, see esp. Scheuerman 2016a, b; Celikates 2016a, b.
} 
crisis management. Although Syriza ultimately did little to build on the vote, it was a form of authorisation nonetheless. (One of the problems of executive discretion in the Euro crisis, by contrast, is that it has generally been the action of elites acting independently of public control mechanisms, and to the extent that they have had an electoral mandate at all it has been one weakly linked to the measures advanced.) One may also highlight more processual forms of recourse to public approval, less open to the charge of plebiscitarianism, based on seeking popular involvement in the formulation of policy, e.g. through participatory forms of party membership. In addition to ex ante forms of authorisation for disobedience, there are also ex post measures - e.g. the calling of elections - by which a readiness to submit actions to public approval can be shown. ${ }^{41}$

On its own, this is a promising but insufficient foundation for principled disobedience. In the European context, the approval that can be sought this way is likely to correspond to national or sub-national institutions. Though it may mark a step away from a purely arbitrary exercise of discretion, it remains compatible with the pursuit of what, from a broader perspective, remain rather parochial ends. Moreover, an anchoring in public support is what far-Right forms of institutional disobedience in the EU tend to claim. When Hungary's ruling Fidesz party took aim at EU rules and proposals on immigration and asylum, it styled this as an elected national government speaking up for the views of its people, with a national referendum intended to underline this. ${ }^{42}$ To be sure, some rather dubious means may be used to manufacture such opinion, ${ }^{43}$ and the populist outlook is generally wary of genuine participation and the party structures that enable it. ${ }^{44}$ But still, some kind of recourse to public evaluation remains evident. This criterion is a necessary but insufficient marker of a defensible politics of disobedience.

b) A further condition of legitimate extra-legality can be expressed as a commitment to generalizable justification. Acts of transgression employed to challenge the existing regime are defensible to the extent they are coupled with a certain kind of normative account of what they are intended to achieve.

\footnotetext{
${ }^{41}$ In discussions of civil disobedience, the principled nature of the act is often said to be signalled by willingness to accept the consequences of breach (i.e. accepting sanction for transgressions). It may be that there are equivalent ex post actions available to disobedient actors working through institutions, including resignations of office.

${ }^{42}$ See the referendum of $2^{\text {nd }}$ October 2016.

${ }^{43}$ For contemporary analysis see: https://www.theguardian.com/world/2016/oct/01/hungarian-referendumslam-door-migrants-new-era-europe

${ }^{44}$ Müller 2016, p.29, p.35.
} 
Typically when crisis is invoked by political leaders the rationale for action is necessity. Measures are presented as steps required in the face of urgent threats for the sake of the polity's survival. By the standards of political justification, this type of framing is weak: it obscures the value choices such actions entail, and denies the possibility of viable alternatives with which the measures advanced may be compared. ${ }^{45}$ A counter-politics, it is true, may also need to draw on ideas of urgent threat to defend its breaking of rules. The discourse of exceptional measures for exceptional times is not so different from the ideas of last resort that are a staple of thinking about civil disobedience. ${ }^{46}$ Emergency claims can galvanise action and build solidarities - they are not intrinsically indefensible. ${ }^{47}$ But if such claims are to underpin legitimate forms of disobedience, distinguishable from the actions they oppose, they can hardly take the form of appeals to bare necessity. Themes of urgency are defensible to the extent they are publicly related to normative ideas about why certain actions are more desirable than others. The breaking of rules is a principled gesture only when coupled with an account of what is valuable and needs to be preserved - of how a given course of action not only allows the polity's survival but its survival in the right form.

A commitment to political justification entails claims concerning generalizable ends. Principled disobedience is never only about advancing the interests of a sectoral grouping. To the extent that such interests are promoted, it is for reasons that others can in principle share: actions taken are on behalf of a wider whole, not simply an effort to extricate particular actors from particular constraints. ${ }^{48}$ In the transnational context, disobedience of the relevant kind is action not solely on behalf of a country, region or other such particularist grouping. Though appeals to the welfare of such groupings may be present, especially when public approval through local institutions is sought, the challenge is to locate these within an argument about the larger interest. Such broader claims, one may note, were prominent in the discourse of Syriza in spring 2015, ${ }^{49}$ and are replicated in the programmatic statements of successor movements such as DiEM25. ${ }^{50}$

\footnotetext{
${ }^{45}$ Cf. White 2015a.

${ }^{46}$ Cf. Scheuerman 2016 b.

${ }^{47}$ Cf. Rubenstein 2015 on the Janus-faced character of emergency thinking.

${ }^{48}$ Cf. Scheuerman 2015, p.7.

${ }^{49}$ See e.g. an early effort to fix the meaning of the result of the $5^{\text {th }}$ July referendum: https://yanisvaroufakis.eu/2015/07/06/our-no-is-a-majestic-big-yes-to-a-democratic-rational-europe/

${ }_{50}$ In addition to Varoufakis 2016, see the DiEM25 manifesto: https://diem25.org/wpcontent/uploads/2016/02/diem25 english_long.pdf
} 
Does this criterion of justification offer a line of demarcation against far-Right forms of disobedience? It offers a separation of sorts, since part of the populist tendency in far-Right politics is exactly to treat as self-evident the truth of the claims advanced. A politics which is essentially non-pluralist is one that has little reason to offer justification for the positions it advances. ${ }^{51}$ It treats the ends it promotes as incontestable, and seeks not to ignite debate and persuade but rather to articulate what 'everyone' is said already to know. Its appeal in the first instance is to authenticity rather than normative reasoning. Still, it would be too quick to suggest that there is no account in far Right populism of why certain ends are to be valued, or that generalised goals are absent. The claim to be acting on behalf of (European, or Christian) civilisation as a whole, rather than a single national people, is characteristic of many contemporary far-Right positions, however exclusionary that conception of civilisation may be. Again, an understanding of principled disobedience needs to be more demanding.

c) Commitment to achieving a genuine constitutional order is a third criterion by which defensible acts of disobedience may be distinguished from other forms of extra-legality. A related criterion is typically invoked in discussions of civil disobedience, where the singular importance of 'very highest respect for the law' is emphasised. ${ }^{52}$ Disobedience is presented as legitimate to the extent it is wrapped up in larger statements and actions of fidelity. It is important to conceive this correctly however. Often the understanding is narrow, as when the disobedient agent is expected to endorse the existing legal order largely as it stands, rejecting only those specific rules it chooses to transgress. ${ }^{53}$ In the case of the EU, where constitutional foundations are imperfect at the best of times, respect for the law should be understood as a broader commitment to a rules-based order, even one quite different from what exists in the present day.

A commitment to the rule of law is typically voiced of course by the agents of emergency rule, certainly when seeking to normalise the regime post hoc. Yet it clearly matters how far such stated commitments are backed by actions. As noted, however energetic has been the production of new rules in the EU since the Euro crisis, they scarcely amount to a demonstrable commitment to a constitutional framework, not only because they leave significant scope for discretion in the hands of powerful actors, but also because their detailed stipulations are likely to fare badly as conditions evolve,

\footnotetext{
${ }^{51}$ Müller 2016, p.20, p.31.

${ }^{52}$ For critical discussion: Scheuerman 2015.

${ }^{53}$ Scheuerman 2015, esp. p.9, 16; see also Celikates 2016a, b.
} 
leaving them vulnerable to further acts of far-reaching revision. To quote Joerges again: 'de-legalisation' is the tendency expressed in this recourse to binding controls. ${ }^{54}$

Commitment to achieving a genuine constitutional order is also where many farRight forms of disobedience are likely to score badly. The non-pluralist tendency in farRight populism typically finds expression exactly in impatience with procedural norms. The tendency is to treat them less as an ideal to be institutionalised than as a threat to the expression of popular identity and common-sense. While pragmatism may encourage such agents to avoid illegality where possible, and even to adopt constitutional measures where they can be shaped to serve the partisan agenda, the tenor of their practice and discourse is generally one of scepticism towards genuine legal constraints. ${ }^{55}$

How might the agents of a principled disobedience demonstrate their commitment to a constitutional order? Perhaps we may speculate the following. Aside from openly stating this goal and advocating measures that plausibly serve it, there is a distinctive opportunity that transnational politics affords to those agents such as parties that pursue disobedience through institutions. Their respect for law and process at the transnational level can, in part, be gauged from their conduct at the national level. ${ }^{56} \mathrm{~A}$ party is typically a disciplined force compared to the civil disobedience of crowds, and one that has entered parliament and / or government at the national level will have had the opportunity, more or less developed, to show its readiness to adhere to electoral and constitutional requirements. A commitment to the principle of a constitutional order though not, of course, to the particulars of the EU framework - is something agents of this kind can credibly indicate, however disobedient their actions transnationally may be.

We may summarise the points of this section as follows. Faced with a legal regime objectionable for its incapacity to bind power, yet plausibly contested only by further exceptional means, the agents of opposition must rely on a distinct normative basis for their actions. I have argued for three standards that express this: a readiness to submit actions to public approval, a commitment to generalizable justification, and a commitment to a genuine constitutional order. Each is a complicated thing in the transnational setting, but each nonetheless serves to mark off principled disobedience from the exceptionalism of emergency rule, as well as from many of the responses to be expected from the far Right. A

\footnotetext{
${ }^{54}$ Joerges in Chalmers, Jachtenfuchs and Joerges 2016.

${ }^{55}$ Müller 2016, p50, p.63.

${ }^{56}$ Only in part: as noted earlier, the insertion of economic rules into the national constitutions of Eurozone states means national and transnational rule-breaking will be increasingly difficult to separate.
} 
politics of disobedience that honours these criteria can plausibly claim normative foundation.

The agents of civil disobedience are typically conceived as crowds and movements in extra-institutional settings. Without arguing for the irrelevance of these, I have noted the affinity that exists in the transnational context between the criteria described and forms of association that harness the power and authority of political institutions. The example of Syriza, and the follow-up movements it has generated, gives a glimpse of how disobedience of this kind might look. At the same time it suggests the limits of such actions in one country alone. A more consequential expression, able to present its goals as irreducible to local concerns, may depend on a conjuncture arising when ruling parties in at least two member-states are able to articulate a common agenda of disobedience.

The focus here has been on the contestation of emergency-led rule-making rather than its prevention. We may note in passing that a model centred on participatory associations may also offer one of the better constraints on executive discretion in the longer term. A partisan collective that ties its leaders into a larger decision-making network and demands that their actions be reconciled with the programmatic commitments of the association may go some way to compensating for the limitations of judicial and other procedural restraints on executive discretion. Where executives are populated by relatively detached representatives, weakly embedded in associative decision-making processes, extralegality is likely to be a persistent temptation, not just a strategy of last resort.

\section{$\underline{\text { Conclusion }}$}

The contestation of emergency measures faces numerous challenges, magnified in the transnational context. As I have sought to indicate, efforts to unpick such measures by ordinary legislative means are likely to founder on the reluctance of agents and their vetoing capacity, while judicial responses face distinct problems of legal and epistemic authority. A strategy of malicious compliance intended to sharpen the regime's contradictions is meanwhile quite uncertain in the outcomes it leads to. This leaves a politics of principled disobedience as one of the few ways to resist the normalisation of measures introduced under the sign of emergency.

Disobedience is primarily about influencing opinion, about putting the legitimacy of current arrangements in question. Simply maintaining some institutional instability is a 
not insignificant objective. More challenging is for disobedience to exert a deeper influence on opinion by finding recognition as a principled stance. The transnational setting raises some distinctive challenges in view of the uncertain constituency for disobedient actions, as well as the long-established tendency to insulate decision-making from popular interference. As the Greek episode in 2015 suggests, such forms of defiance must contend not only with the possibility that they meet with indifference, but with the efforts of the regime's defenders to portray disobedience as unprincipled recalcitrance, as one more reason to insist on the rules.

The opportunity to wage disobedience through political institutions is one of the intriguing features of the transnational realm. Rethinking the agents as intermediary associations like parties is one way to acknowledge this potential without discarding the moral features characteristic of principled disobedience. I have sought to highlight three standards by which defensible actions of this kind can be recognised. Though its disobedience in 2015 was ultimately more threatened than performed, Syriza could at least credibly claim to have sought popular backing for a policy of non-compliance, to have offered generalizable justification for such actions, and to have expressed its underlying commitment to a genuine constitutional order. The normative basis for its challenge deserves recognition, particularly given the potential for similar but less acceptable forms of disobedience to emerge from the far Right. Its slim practical effects suggest either that the EU is beyond reform - a possibility that disobedience must always contend with - or that efforts to reform it depend heavily on a favourable arrangement of political forces crossnationally.

\section{$\underline{\text { References }}$}

Ackerman, Bruce A. (1991), We the People: Foundations (Cambridge, MA: Harvard UP).

Aradau, Claudia (2004), 'Security and the democratic scene: desecuritization and emancipation', Journal of International Relations and Development 7, pp. 388-413.

Baquerro-Cruz, Julio (2012), 'Legal Pluralism and Institutional disobedience in the European Union', in Matej Avbelj \& Jan Komárek (eds.) Constitutional Pluralism in the European Union and Beyond (Oxford: Hart).

Beck, Ulrich (2013), German Europe (Cambridge: Polity).

Blyth, Mark (2013), Austerity: The History of a Dangerous Idea (Oxford: OUP).

Celikates, Robin (2016a), 'Rethinking Civil Disobedience as a Practice of Contestation-Beyond the Liberal Paradigm', Constellations 23 (1).

--- (2016b), 'Democratizing civil disobedience', Philosophy and Social Criticism 42 (10), pp.982-94.

Dean, Jodi (2016), Crowds and Party (London: Verso).

Della Porta, Donatella and Daniela Chironi (2015), 'Movements in Parties: OccupyPD', Partecipazione e Conflitto $(P A C O) 8(1)$.

Douzinas, Costas (2013), Philosophy and Resistance in the Crisis (Cambridge: Polity).

--- (2015), 'Radical Philosophy Encounters the Uprisings: Lessons from Greece', in Robin Celikates, Regina Kreide, and Tilo Wesche (eds), Transformations of Democracy: Crisis, Protest, and Legitimation (London: Rowman \& Littlefield International), pp.65-82. 
Dyzenhaus, David (2006). The Constitution of Law: Legality in a Time of Emergency (Cambridge: CUP).

Fischer-Lescano, Andreas (2014), Human Rights in Times of Austerity Policy: The EU Institutions and the Conclusion of Memoranda of Understanding (Baden-Baden: Nomos).

Goodin, Robert E. (2005), 'Toward an international rule of law: distinguishing international law-breakers from would-be law-makers', Journal of Ethics 9, pp.225-46.

Habermas, Jürgen (2015), The Lure of Technocracy, trans. Ciarin Cronin (Cambridge: Polity).

Innerarity, Daniel (2014), 'Does Europe need a Demos to be Truly Demoratic?', LSE Europe in Question Series (LEQS), No. 77.

Joerges, Christian (2016), 'What is left of the European Economic Constitution II? From Pyrrhic Victory to Cannae Defeat', in Poul F. Kjaer and Niklas Olsen (eds.), Critical Theories of Crisis in Europe: From Weimar to the Euro (Rowman \& Littlefield).

Kilpatrick, Claire (2015), 'On the Rule of Law and Economic Emergency: The Degradation of Basic Legal Values in Europe's Bailout', Oxford Journal of Legal Studies 35, pp.325-53.

Kreuder-Sonnen, Christian (2016), 'Beyond integration theory: the (anti-)constitutional dimension of European crisis governance', Journal of Common Market Studies 54 (6), pp.1350-66.

Kumm, Mathias (2012), 'Constitutionalism and the Moral Point of Constitutional Pluralism: Institutional Civil Disobedience and Conscientious Objection', in Julie Dickson and Pavlos Eleftheriades (eds.) Philosophical Foundations of EU Law (Oxford: OUP).

Müller, Jan-Werner (2016), What is Populism? (Philadelphia,: U. of Pennsylvania).

Rawls, John (1999 [1971]), A Theory of Justice (Cambridge MA: Harvard UP).

Rubenstein, Jennifer C. (2015), 'Emergency Claims and Democratic Action', Social Philosophy and Policy 32, pp.101-26.

Schaeffer, David (2015), 'A Banking Union of Ideas? The Impact of Ordoliberalism and the Vicious Circle on the EU Banking Union', Journal of Common Market Studies

Scharpf, Fritz (2014), 'Political Legitimacy in a Non-optimal Currency Area', in Sara Hobolt and Olaf Cramme (eds), Democratic Politics in a European Union under Stress (Oxford: OUP).

Scheuerman, William (2016a), 'Civil disobedience in the shadows of postnationalization and privatization', Journal of International Political Theory 12(3) 237-57

--- (2016b), 'Crises and Extra-Legality: From Above and from Below', in Poul F. Kjaer and Niklas Olsen (eds.), Critical Theories of Crisis in Europe: From Weimar to the Euro (Rowman \& Littlefield).

--- (2015), 'Recent Theories of Civil Disobedience: An Anti-Legal Turn?', Journal of Political Philosophy.

Scicluna, Nicole (2014), 'Politicization without democratization: How the Eurozone crisis is transforming EU law and politics', International Journal of Constitutional Law 12 (3), pp.545-71.

Varoufakis, Yanis (2016), 'Europe's Left after Brexit', $8^{\text {th }}$ September (https://yanisvaroufakis.eu/2016/09/08/europes-left-after-brexit/).

Wagner, Rikke (2015), 'Transnational civil dis/obedience' in the Danish family unification dispute', European Political Science Review 7 (1), pp. 43-62.

White, Jonathan (2015a), 'Emergency Europe', Political Studies 63 (2), pp.300-18.

White, Jonathan (2015b), 'Authority after Emergency Rule', Modern Law Review 78 (4), pp.585-610.

White, Jonathan (2014), 'Transnational Partisanship: Idea and Practice', Critical Review of International Social and Political Philosophy 17 (3), pp.377-400.

White, Jonathan (2011), Political Allegiance after European Integration (Basingstoke: Palgrave Macmillan). 